\title{
Cendekia Journal of
}

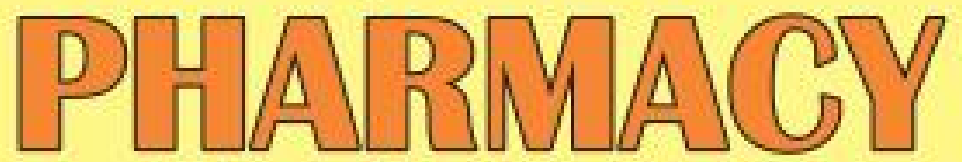

Vol. 2 No. 2

P.ISSN $2599-2168$

November 2018 E-ASSN $2599-2155$

Uji Aktivitas Antioksidan Ekstrak Rebung Bambu Apus (Gigantochloa apus

Kurz) terhadap 1,1-Diphenyl-2- Picrylhidrazyl (DPPH)

Edy Soesanto

Pengaruh Ekstrak Etanol Ranting Buah Parijoto (medinilla speciosa blume)

Terhadap Kadar Glukosa Darah Tikus Putih dengan Metode Induksi Aloksan

Annik Megawati, Endra Pujiastuti

Pengembangan Bionanokomposit dalam Drug Delivery Systems (Dds)

Berbasis Pati Ganyong (Canna discolor)

Ina Ristian, Yulia Pratiwi

Pengaruh Pemberian Minyak Zaitun terhadap Ketebalan Epitel Bronkus

Mencit Asthma

Dian Arsanti Palupi, Fajrunida Nur Hasanah

Potensi Gel Antiacne Ekstrak Buah Parijoto (Medinilla Speciosa, Blume) terhadap Bakteri Penyebab Jerawat Propionibacteriumacnes dan

Staphylococcus epidermis

Lilis Sugiarti, Ayun Muzlifah

Pengaruh Perendaman $\mathrm{NaCl}$ Terhadap Kadar Glukomanan dan Kalsium

Oksalat Tepung lles-lles (Amorphophallus Variabilis Bi)

Diah Anita Nurul Ulfa, Rohmatun Nafi'ah

Uji Perbedaan Aktivitas Antioksidan dengan Variasi Konsentrasipelarut

Etanol $70 \%$ dan $96 \%$ pada Ekstrak Etanol Daun Salam Menggunakan Metode

Peredaman Radikal Bebas DPPH

Ricka Islamiyati, Ika Noviana Saputri

Absorbsi Amoxicillin Pada Tikus Galur Wistar dan Galur Sprague Dawley Rizkyana Efendi, Wirasti, Ainun Muthoharoh

Formulasi Mouthwash Ekstrak Etanol Daun Kemangi (Ocimum basilicum L) Wulan Agustin Ningrum, Urmatul Waznah

Optimasi Formula Gel Ekstrak Daging Limbah Tomat (Lycopersicum

Esculentul Mill) Dan Uji Aktivitas terhadap Lama Penyembuhan Luka Insisi pada Kelinci

Dzun Haryadi Ittiqo, Susliana Agustina 
Volume 2 No. 2

P-ISSN $2559-2163$

November 2018

\title{
Cendekia Journal of \\ PHARMACY
}

\author{
Editor In Chief
}

Annik Megawati, STIKES Cendekia Utama Kudus, Indonesia

\section{Editorial Board}

Dian Arsanti Palupi, STIKES Cendekia Utama Kudus, Indonesia Ema Dwi Hastuti, STIKES Cendekia Utama Kudus, Indonesia Endra Pujiastuti, STIKES Cendekia Utama Kudus, Indonesia

Lilis Sugiarti, STIKES Cendekia Utama Kudus, Indonesia

\section{Reviewer}

Parno Widjojo, Universitas Diponegoro Semarang, Indonesia

Eko Prasetyo, STIKES Cendekia Utama Kudus, Indonesia

Siti Musdalifah, RSUD dr.Loekmono Hadi Kudus, Indonesia

\section{English Language Editor}

Arina Hafadhotul Husna, STIKES Cendekia Utama Kudus, Indonesia

\section{IT Support}

Susilo Restu Wahyuno, STIKES Cendekia Utama Kudus, Indonesia

\author{
Penerbit \\ Program Studi Farmasi \\ STIKES Cendekia Utama Kudus
}

\begin{abstract}
Alamat
Jalan Lingkar Raya Kudus - Pati KM.5 Jepang Mejobo Kudus 59381

Telp. (0291) 4248655, 4248656 Fax. (0291) 4248651

Website : www.jurnal.stikescendekiautamakudus.ac.id

Email : jurnal@stikescendekiautamakudus.ac.id
\end{abstract}

\section{Cendekia Journal of Pharmacy merupakan Jurnal Ilmiah dalam bidang Ilmu dan Teknologi Farmasi yang diterbitkan oleh Program Studi Farmasi STIKES Cendekia Utama Kudus secara berkala dua kali dalam satu tahun.}




\section{DAFTAR ISI}

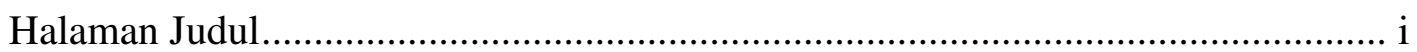

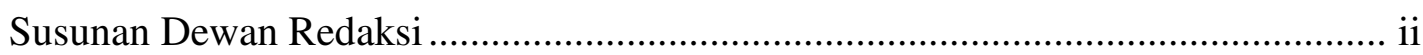

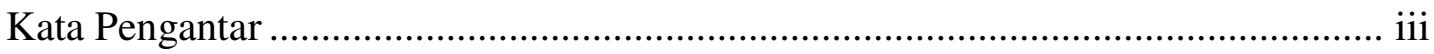

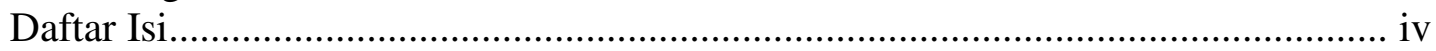

Uji Aktivitas Antioksidan Ekstrak Rebung Bambu Apus (Gigantochloa apus Kurz) terhadap 1,1-Diphenyl-2- Picrylhidrazyl (DPPH)

Edy Soesanto 88

Pengaruh Ekstrak Etanol Ranting Buah Parijoto (medinilla speciosa blume) Terhadap Kadar Glukosa Darah Tikus Putih Dengan Metode Induksi Aloksan

Annik Megawati, Endra Pujiastuti

Pengembangan Bionanokomposit dalam Drug Delivery Systems (Dds) Berbasis Pati Ganyong (Canna discolor)

Ina Ristian, Yulia Pratiwi

Pengaruh Pemberian Minyak Zaitun terhadap Ketebalan Epitel Bronkus Mencit Asma

Dian Arsanti Palupi, Fajrunida Nur Hasanah

Potensi Gel Antiacne Ekstrak Buah Parijoto (Medinilla Speciosa, Blume) terhadap Bakteri Penyebab Jerawat Propionibacteriumacnes dan Staphylococcus epidermis

Lilis Sugiarti, Ayun Muzlifah

Pengaruh Perendaman NaCl Terhadap Kadar Glukomanan dan Kalsium Oksalat Tepung Iles-Iles (Amorphophallus Variabilis Bi)

Diah Anita Nurul Ulfa, Rohmatun Nafi'ah

Uji Perbedaan Aktivitas Antioksidan dengan Variasi Konsentrasipelarut Etanol 70\% dan 96\% pada Ekstrak Etanol Daun Salam Menggunakan Metode Peredaman Radikal Bebas DPPH

Ricka Islamiyati, Ika Noviana Saputri

Absorbsi Amoxicillin Pada Tikus Galur Wistar dan Galur Sprague Dawley Rizkyana Efendi, Wirasti, Ainun Muthoharoh

Formulasi Mouthwash Ekstrak Etanol Daun Kemangi (Ocimum basilicum L)

Wulan Agustin Ningrum, Urmatul Waznah..... 
Optimasi Formula Gel Ekstrak Daging Limbah Tomat (Lycopersicum Esculentul Mill) Dan Uji Aktivitas terhadap Lama Penyembuhan Luka Insisi pada Kelinci

Dzun Haryadi Ittiqo , Susliana Agustina.................................................................167

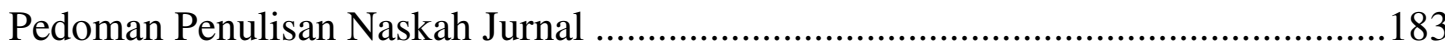




\title{
OPTIMASI FORMULA GEL EKSTRAK DAGING LIMBAH TOMAT (Lycopersicum esculentul Mill) DAN UJI AKTIVITAS TERHADAP LAMA PENYEMBUHAN LUKA INSISI PADA KELINCI
}

\author{
Dzun Haryadi Ittiqo ${ }^{1}$, Susliana Agustina ${ }^{2}$ \\ Program Studi D3 Farmasi UMMAT \\ Jl. KH.Ahmad Dahlan No.01 Pagesangan Mataram, NTB 83127 \\ Email dzun.haryadi@gmail.com, anhaagustina@gmail.com
}

\begin{abstract}
ABSTRAK
Luka insisi adalah luka akibat terpotongnya jaringan oleh goresan benda tajam. Senyawa golongan flavonoid dan saponin telah dibuktikan secara pre klinis dapat mempercepat penyembuhan luka. Tomat mengandung senyawa saponin dan bioflavonoid, sehingga diperkirakan memiliki potensi sebagai obat penyembuh luka. Penelitian ini merupakan penelitian eksperimental. Metode optimasi menggunkan D-optimal dengan software design exspert versi 7.1.5. Komponen yang dioptimasi adalah formula standar gel basis natrium karboksimetil selulosa (Na-CMC) dan propilenglikol, respon yang dinilai adalah daya lekat, daya sebar dan $\mathrm{pH}$. Formula optimum gel dilakukan diuji stabilitas dan aktivitas terhadap lama penyembuhan luka insisi pada kelinci. Hewan uji dibagi dalam empat kelompok yaitu kelompok kontrol negatif (basis gel), kontrol positif (betadin salap $10 \%$ ), formula optimum dan tanpa perlakuan. Punggung kelinci dibuat luka insisi sepanjang $3 \mathrm{~cm}$ dan kedalaman $0,3 \mathrm{~cm}$, luka diolesi sampel uji sebanyak dua kali sehari selama 7 hari. Pengamatan dilakukan dengan mengukur panjang luka selama perlakuan. Data diuji statistik dengan metode ANOVA dilanjutkan dengan uji LSD (Last significant different). Berdasarkan hasil penelitian, kombinasi CMC-Na dan propilenglikol mempengaruhi $\mathrm{pH}$, daya sebar dan daya lekat. Porsentase formula optimum bahan teroptimasi gel yang dihasilkan untuk CMC-Na dan Propilenglikol masing-masing adalah $3,50 \%$ dan $11,50 \%$ dengan parameter nilai mutu fisik untuk $\mathrm{pH} 6,09$, daya sebar 10,38 $\mathrm{cm}^{2}$, daya lekat $12,32 \mathrm{detik}$. Formula gel optimum memiliki kestabilan yang baik terbukti dari tidak terjadinya sineresis pada saat penyimpanan dengan suhu berbeda yaitu $10^{\circ} \mathrm{C}$ dan $30^{\circ} \mathrm{C}$.Analisis statistik menunjukkan aktivitas penyembuhan luka formula optimum berbeda signifikan dibandingkan dengan kontrol negatif dan tanpa perlakuan.
\end{abstract}

Kata kunci : Gel, Lycopersicum esculentum Mill, D-optimal, Luka Insisi.

\section{ABSTRACT}

The incision wound is a wound due to the cutting of the tissue by sharp objects. Flavonoid and saponin compounds have been clinically proven to accelerate wound healing. Tomatoes contain saponin and bioflavonoid compounds, so they are thought to have potential as wound healing drugs. This research is an experimental research. Optimization method using D-optimal with software design expert version 7.1.5. The optimized component is a standard gel formula based on sodium carboxymethyl cellulose (Na-CMC) and propylene glycol, the rated response is $\mathrm{pH}$, dispersion and stickiness. The optimum gel formula was tested for stability and activity on the length of incision wound healing in rabbits. Test animals were divided into four groups: negative control group (base gel), positive control (10\% betadin ointment), optimum formula and no treatment. 
Rabbit's back incision wound $3 \mathrm{~cm}$ long and $0.3 \mathrm{~cm}$ deep, the wound is smeared with test samples twice a day for 7 days. Observations were made by measuring the length of the wound during the treatment. Data were tested statistically by ANOVA method followed by LSD test (Last significant different). Based on the results of the study, the combination of $\mathrm{CMC}-\mathrm{Na}$ and propylene glycol affect $\mathrm{pH}$, dispersion and stickiness. Percentage of optimum formula for gel optimized ingredients produced for $\mathrm{CMC}-\mathrm{Na}$ and Propylene glycol were $3.50 \%$ and $11.50 \%$ respectively with physical quality values for $\mathrm{pH}$ 6.09, dispersion $10.38 \mathrm{~cm} 2$, stickiness 12.32 seconds. The optimum gel formula has good stability proven by the absence of sineresis during storage with different temperatures of $10^{\circ} \mathrm{C}$ and $30^{\circ} \mathrm{C}$. Statistical analysis showed that optimum formula wound healing activity was significantly different compared to negative and untreated controls.

Keywords: Gel, Lycopersicum esculentum Mill, D-optimal, Incisional Wounds

\section{LATAR BELAKANG}

Luka adalah suatu kerusakan bagian tubuh yang terjadi pada kulit berupa jaringan yang terputus, robek, atau rusak oleh karena suatu sebab(Librianty, 2015). Salah satu jenis luka adalah luka insisi, luka insisi adalah luka dengan gambaran garis tepi luka yang rapi,seperti luka ringan yang terjadi akibat irisan oleh instrumen tajam atau insisi saat pembedahan (Wombeogo and Kuubire, 2014)

Obat topikal sintesis yang umum digunakan pada luka insisi adalah kompres iodium povidon atau nitras-argenti $0,5 \%$ yang berperan sebagai bakteriostatik untuk semua kuman(Sjamsu, 2005) Tetapi penggunaan iodium povidon dan nitras-argenti yang berlebihan dapat menimbulkan efek samping berupa dermatitis, bengkak, gatal dan rangsangan nyeri yang sangat pada daerah sekitar luka (Afiyanti and Rachmawati, 2014)

Variasi tanaman sangat banyak di alam yang telah dimanfaatkan oleh masyarakat, baik sebagai bahan makanan maupun sebagai bahan obat-obatan, salah satunya tanaman tomat. Tomat sebagai komuditi pertanian untuk keperluan rumah tangga apabila sudah matang akan mengandung air tidak kurang dari $95 \%$ sehingga kandungan tersebut menyebabkan tomat mudah membusuk atau mudah rusak secara fisik. Tomat yang rusak hanya dijadikan limbah yang tidak bermanfaat dan sering menimbulkan masalah bagi lingkungan karena belum adanya upaya pengolahan menjadi produk yang bermanfaat (Sumardiono, Basri and Pasonang Sihombing, 2009)

Tomat mengandung beberapa senyawa kimia, dua diantaranya adalah saponin dan bioflavonoid. Senyawa golongan flavonoid, saponin dan tanin telah dibuktikan secara pre klinis bisa mempercepat penyembuhan luka (Suhartati, 2015) Bentuk sediaan dengan rute topikal sangat disukai, salah satunya adalah gel. Sediaan gel mempunyai beberapa sifat yang disukai seperti alirannya yang tiksotropik, tidak lengket, mudah menyebar, mudah dibersihkan, kompatibel dengan beberapa eksipien dan larut dalam air(Soebagio and Rusdiana, 2007). Untuk mendapatkan sediaan gel yang bermutu dengan kualitas yang baik maka diperlukan optimasi formula dengan memperhatikan konsentrasi serta karakteristik bahan yang digunakan. Design Expert adalah software yang 
diproduksi oleh stateease, merupakan metode statistik yang khusus digunakan untuk melakukan desain eksperimental yaitu untuk menentukan formula optimum(Tiaraswara, 2015).

Berdasarkan informasi diatas, dianggap penting melakukan penelitian tentang optimasi formula gel ekstrak daging limbah tomat (Licopersicum esculentum Mill) dan uji aktivitas terhadap lama penyembuhan luka insisi pada kelinci.

\section{BAHAN DAN METODE PENELITIAN}

\section{Desain Penelitian}

Penelitian ini menggunakan desain penelitian eksperimental yang merupakan penelitian laboratorium dengan metode D-Optimal.

\section{Tempat dan Waktu Penelitian}

Penelitian ini dilakukan pada bulan Juni-Agustus tahun 2018 di Laboratorium Farmakognosi dan Teknologi Farmasi D3 Farmasi Universitas Muhammadiyah Mataram.

\section{Sampel Penelitian}

Daging limbah tomat yang diperoleh dari lahan pertanian tanaman buah tomat yang berada di Desa Gili Sasak, Kecamatan Kuripan Kabupaten Lombok Barat

Kriteria Sampel :

1. Kriteria Inklusi : Daging limbah tomat cacat tidak layak jual dan tanpa biji.

2. Kriteria Eksklusi : Daging limbah tomat yang busuk.

\section{Variabel Penelitian}

Variabel bebas dalam penelitian ini adalah Formulasi gel yang meliputi CMC-Na, gliserin, propilenglikol, aquadest, dan serbuk daging limbah tomat.Variabel terikat lama penyembuhan luka insisi pada hewan uji sedangkan variabel moderat yaitu uji sifat fisik gel meliputi uji $\mathrm{pH}$, uji daya sebar, dan uji daya lekat.

\section{Instrumen Penelitian}

1. Alat

Neraca analitik digital, alat-alat gelas, mesh no.60, mortir danstemper, blender, kompor, oven, sendok tanduk, mistar, lap, tissue, nampan, sudip, batang pengaduk, kertas perkamen, kaca arloji, pipet tetes, termometer, $\mathrm{pH}$ meter, pot gel, alat uji daya lekat dan daya sebar, masker, sarung tangan, stopwatch, kandang kelinci, alat cukut, surgical blade steril nomor 11.

2. Bahan

Daging limbah buah tomat, aquadest, CMC-Na, gliserin, propilenglikol, dan etil klorida spray sebagai anastesi lokal untuk hewan uji. Subjek uji penelitian ini adalah kelinci

\section{Prosedur Penelitian}

1. Persiapan Sampel

Sampel yang telah didapatkan dibersihkan, dipisahkan dari bagian yang sedikit rusak dan bijinya. Bagian buah yang digunakan adalah daging buah tomat tanpa bijinya, lalu dipotong kecil-kecil menjadi beberapa bagian. Dikeringkan dalam oven pada suhu $60-80^{\circ} \mathrm{C}$ sampai kering(Agoes, 2007). 
2. Pembuatan Ekstrak

Pembuatan ekstrak daging limbah buah tomat (Lycopersicum esculentum Mill) sebanyak 50 gram simplisia limbah tomat kemudian dimasukkan ke dalam gelas kimia. Tambahkan pelarut etanol 70\% sebanyak $500 \mathrm{ml}(1: 10)$ kemudian dilakukan maserasi selama 24 jam sambil sesekali diaduk. Setelah 24 jam, maserat yang terbentuk diambil, lalu tambahkan lagi etanol lalu maserasi lagi, ulangi sampai maserat menjadi jernih. Campur semua ekstrak encer pada satu tempat. Kemudian dievavorasi dengan menggunakan alat rotary evavorator dengan suhu $80^{\circ} \mathrm{C}$ sehingga diperoleh ekstrak kental(Departement Kesehatan, 2000)

3. Optimasi formula gel

Formula Standar yang digunakan adalah formula standar gel basis natrium karboksimetil selulosa (Na-CMC) dengan komponen gliserin, Propilenglikol dan aquades. Optimasi formula menggunakan design exspert versi 7.1.5. Komponen yang dioptimasi adalah natrium karboksimetil selulosa (Na-CMC) dan propilenglikol, parameter atau respon yang dinilai adalah daya lekat, daya sebar dan $\mathrm{pH}($ Aponno, 2014).

4. Pembuatan Gel

Pembuatan gel diawali dengan menyiapkan semua bahan yang akan digunakan. Bahan ditimbang sesuai dengan formula yang ada. Ekstrak dilarutkan dalam sebagian air yang telah dipanaskan pada suhu $50^{\circ} \mathrm{C}$, ditambahkan CMC-Na dan diaduk hingga homogen. Ditambahkan gliserin, propilenglikol dan air dengan pengadukan secara kontinyu hingga terbentuk gel (Aponno, 2014).

5. Uji Sifat Fisik Sediaan

a. $\mathrm{PH}$

$100 \mathrm{mg}$ formula gel ditimbang dalam labu ukur $50 \mathrm{~mL}$ selanjutnya ditambahkan aquadest sampai $50 \mathrm{~mL}$ (konsentrasi 0,2\%). $\mathrm{pH}$ gel dicatat dengan $\mathrm{pH}$ meter, $\mathrm{pH}$ meter dibiarkan kontang dengan sel selama 1 menit. Percobaan ini untuk memeriksa netralitas gel antar batch yang berbeda (Chaudhary et al., 2011)

b. Daya Sebar

Setengah gram formula gel diletakkan di pusat antara 2 lempeng gelas, dimana lempeng sebelah atas ditimbang terlebih dahulu kemudian diletakkan diatas gel dan dibiarkan selama 1 menit. Diatasnya diberi beban $150 \mathrm{~g}$, dibiarkan 1 menit dan ukur diameter sebarnya. Pengamatan dilakukan setiap minggu selama 4 minggu (Purwanto, Mufrod and NSP, 2015).

c. Daya Lekat

Gelas objek ditandai 4 × 2,5 cm, kemudian sebanyak $0,25 \mathrm{~g}$ gel diletakkan dititik tengah luasan tersebut dan ditutup dengan gelas objek lain. Beri beban $1 \mathrm{~kg}$ selama 5 menit, Kedua gelas objek yang telah saling melekat satu sama lain dipasang pada alat uji yang diberi beban $80 \mathrm{~g}$. Dicatat waktu yang diperlukan hingga terpisahnya dua objek gelas tersebut. Pengamatan dilakukan setiap minggu selama 4 minggu (Purwanto, Mufrod and NSP, 2015). 
6. Uji aktivitas lama penyembuhan luka formula gel optimum.

a. Penyiapan hewan uji dan pembuatan luka

Pada punggung kelinci terlebih dahulu dianestesi lokal menggunakan etil klorid spray lalu dibuat luka insisi menggunakan pisau bedah. Pada masingmasing area dibuat luka dengan ukuran $3 \mathrm{~cm}$ dengan kedalaman 0,3 cm(Ramdani, Mambo and Wuisan, 2014).

b. Pembagian kelompok uji dan pengamatan

Pengujian dibagi menjadi empat kelompok sebagai berikut:

Kelompok 1: Luka di beri formula optimum gel

Kelompok 2: luka diberi betadin salap 10\%

Kelompok 3: Luka diberi basis gel

Kelompok 4: Tidak diberikan perlakuan apa-apa.

Masing-masing kelompok di replikasi 3 kali, area luka di olesi sampel uji 2 kali sehari selama 7 hari. Pengamatan dilakukan dengan mengukur panjang luka selama perlakuan.

c. Uji Stabilitas Formula Optimum Dengan Metode Cyling Test

Uji stabilitas dilakukan untuk mengetahui kualitas sediaan gel serbuk getah ashitaba, apakah sediaan gel yang dibuat mengalami perubahan sifat fisik, Gel disimpan pada suhu $10^{\circ} \mathrm{C}$ selama 24 jam lalu dikeluarkan dan ditempatkan pada suhu $30^{\circ} \mathrm{C}$ selama 24 jam. Perlakuan ini adalah satu siklus.Percobaan diulang sebanyak 3 siklus. Sineresis adalah proses dimana cairan terpisah dari gel(Farmasi, 2014).

7. Analisis data dengan pendekatan D-Optimal menggunakan Design Expert versi 7.1.5.

\section{HASIL DAN PEMBAHASAN \\ Pembuatan Ekstrak}

Sebanyak $200 \mathrm{~g}$ serbuk daging limbah tomat di maserasi menggunakan pelarut etanol $70 \%$ menghasilkan 35,88 g ekstrak dengan rendemen 17,94\%. Maserasi dipilih karena dapat mengekstrak senyawa dengan baik dan dapat mencegah dekomposisi senyawa yang labil terhadap pemanasan.

\section{Uji kwalitatif kandungan senyawa}

Sebelum melakukkan penelitian dilakukan uji pendahuluan atau uji senyawa yang terkandung dalam limbah tomat tersebut, meliputi uji alkaloid dan saponin.Hasil uji dapat dilihat pada tabel 1

Tabel 1

Hasil Uji Pendahuluan Senyawa Metabolitme Sekunder Limbah Tomat

\begin{tabular}{cc}
\hline Senyawa & Hasil \\
\hline Alkaloid & - \\
\cline { 2 - 2 } & + \\
\hline Flavonoid & + \\
\hline Saponin & + \\
\hline
\end{tabular}

Keterangan: (+) positif: mengandung golongan senyawa; (-) negatif: tidak mengandung golongan senyawa. 


\section{Pembuatan Gel}

Pembuatan gel dengan zat aktif ekstrak limbah tomat. Bahan pembentuk gel yang biasa digunakan adalah Carbopol, CMC-Na dan HPMC. Pada penelitian ini digunakan basis gel CMC-Na. Komponen lain dalam formula gel antara lain gliserin yang berfungsi sebagai humektan dan menjaga stabilitas sediaan, propilen glikol untuk meningkatkan kelarutan, aquadest digunakan sebagai pelarut sekaligus fase air. Aquadest adalah pelarut yang umum digunakan dalam sediaan semisolida karena bersifat netral, tidak berwarna, tidak berbau, kompatibel dengan hampir semua bahan tambahan, dan dapat membantu masuknya bahan aktif dengan cara menghidrasi stratum korneum. Sedangkan propilen digunakan sebagai humektan atau untuk mempercepat kelarutan dan sebagai pelarut campur sehingga tidak terjadi pengendapan (Rowe, R.C., Sheskey, P. J., Owen, 2006).

Sediaan gel dibuat dengan teknik pencampuran, yakni dilarutkan CMC-Na dilarutkan terlebih dahulu agar terbentuk masa gel kemudian diaduk hingga homogen, ditambahkan serbuk, gliserin, propilenglikol dan sisa air dengan pengadukan secara kontinyu hingga terbentuk gel.

\section{Desain Formula Sediaan Gel Ekstrak Daging Limbah Tomat dengan Design Expert 7.1.5.}

Optimasi formula gel menggunakan Design Expert dengan metode $D$ Optimal. Sebelumnya ditentukan porsentase aras bawah dan aras atas komponen teroptimasi berdasarkan range penggunaan sediaan topikal yang terdapat pada Handbook of Pharmaceutical Excipients. Nilai persentase terendah sampai tertinggi komponen penyusun gel pada penelitian ini dapat dilihat pada tabel 2 .

Tabel 2

\section{Persentase aras bawah dan atas optimasi bahan gel ekstrak daging} limbah tomat

\begin{tabular}{cc}
\hline Persentase Aras Bawah dan Aras Atas Bahan Teroptimasi \\
\hline CMC-Na & Propilenglikol \\
$2 \%-5 \%$ & $10 \%-13 \%$ \\
\hline
\end{tabular}

Nilai persentase terendah sampai tertinggi. Dimasukan ke dalam design dan didapatkan sebanyak 13 run. Selanjutnya dibuat dengan respon meliputi $\mathrm{pH}$, daya sebar dan daya lekat.Seperti yang tertera pada tabel 3.

Tabel 3

Desain dan hasil respon formula gel ekstrak daging limbah tomat

\begin{tabular}{|c|c|c|c|c|c|}
\hline Run & $\begin{array}{c}\text { Komponen } \\
1(\%)\end{array}$ & $\begin{array}{c}\text { Komponen } \\
2(\%)\end{array}$ & $\begin{array}{c}\text { Respon } \\
1\end{array}$ & $\begin{array}{l}\text { Respon } \\
2\left(\mathrm{~cm}^{2}\right)\end{array}$ & $\begin{array}{c}\text { Respon } \\
3 \text { (detik) }\end{array}$ \\
\hline & $\mathrm{CMC}-\mathrm{Na}$ & Propilenglikol & $\overline{\mathrm{PH}}$ & Daya Sebar & Daya Lekat \\
\hline 1 & 3,50 & 11,50 & 6,30 & 11,19 & 8,18 \\
\hline 2 & 4,62 & 10,38 & 6,00 & 8,81 & 46,10 \\
\hline 3 & 2,00 & 13,00 & 6,10 & 16,43 & 1,58 \\
\hline
\end{tabular}




\begin{tabular}{cccccc}
\hline Run & $\begin{array}{c}\text { Komponen } \\
\mathbf{1}(\boldsymbol{\%})\end{array}$ & $\begin{array}{c}\text { Komponen } \\
\mathbf{2}(\mathbf{\%})\end{array}$ & $\begin{array}{c}\text { Respon } \\
\mathbf{1}\end{array}$ & $\begin{array}{c}\text { Respon } \\
\mathbf{2}\left(\mathbf{c m}^{\mathbf{2}}\right)\end{array}$ & $\begin{array}{c}\text { Respon } \\
\mathbf{3}(\mathbf{d e t i k})\end{array}$ \\
\hline 4 & 2,38 & 12,62 & 6,20 & 11,19 & 11,45 \\
5 & 4,24 & 10,76 & 6,10 & 8,42 & 13,20 \\
6 & 5,00 & 10,00 & 6,10 & 7,79 & 23,58 \\
7 & 2,00 & 13,00 & 6,20 & 12,72 & 1,52 \\
8 & 5,00 & 10,00 & 5,90 & 7,42 & 14,81 \\
9 & 12,24 & 10,00 & 5,90 & 6,95 & 5,30 \\
10 & 2,76 & 12,24 & 6,10 & 11,64 & 3,69 \\
11 & 3,87 & 11,13 & 6,00 & 6,60 & 18,02 \\
12 & 2,00 & 13,00 & 6,30 & 15,37 & 1,00 \\
13 & 3,50 & 11,50 & 6,00 & 9,62 & 14,00 \\
& Rata-rata & & 6,09 & 10,31 & 12,49 \\
\hline
\end{tabular}

Masing-masing formula dibuat dengan bobot 25 gr dengan komposisi bahan teroptimasi CMC-Na dan propilen glikol ditambahkan ekstrak limbah tomat 5\%, gliserin $10 \%$ dan aquadest hingga 100\%. Kemudian dilanjutkan uji respon meliputi $\mathrm{pH}$, daya sebar dan daya lekat. Dari nilai respon yang didapatkan dimasukan ke dalam design untuk dilakukan analisis sesuai parameter masingmasing antara lain:

\section{Hasil pH}

Uji $\mathrm{pH}$ dilakukan untuk melihat tingkat keasaman sediaan gel guna menjamin gel yang dihasilkan tidak mengiritasi kulit. $\mathrm{pH}$ suatu sediaan topikal harus sesuai dengan $\mathrm{pH}$ kulit yaitu 4,5-6,5. apabila $\mathrm{pH}$ sediaan $<4,5$ kulit akan mengiritasi, sedangkan apabila pHnya $>6,5$ kulit akan jadi kering (Tranggono, R.I., 2007). Hasil uji pH pada 13 formula yang dihasilkan design berada pada rentang yang dipersyaratkan. Respon $\mathrm{PH}$ yang dihasilkan diuji normalitas nya dengan Design. Analisis kurval normal plot of residu menunjukan bahwa data terdistribusi normal seperti tampak pada gambar 1. Kurva dibuat dengan memplot-kan data normal \% probability dengan internally studentized residuals yang merupakan nilai simpangan baku antara nilai respon hasil prediksi dengan nilai observasi

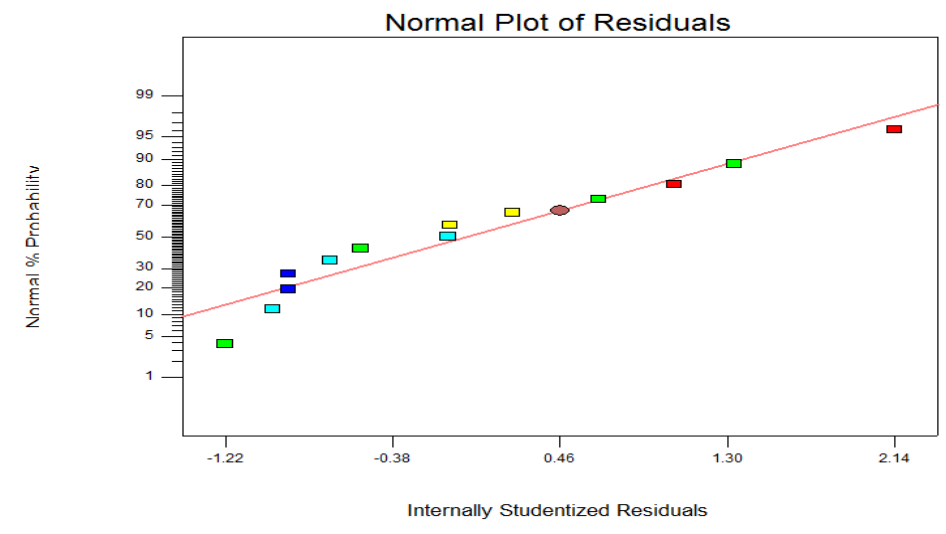

Gambar 1

Kurva Normal Plot Of Residuals pH 
Internally studentized residuals diperoleh dengan cara membagi antara nilai selisih respon observasi dan respon prediksi dengan nilai standar deviation dari selisih kedua respon tersebut. Berdasarkan kurva diatas terlihat bahwa data menyebar disekitar garis diagonal dan mengikuti arah garis diagonal yang menandakan bahwa data terdistribusi normal sehingga dapat dilanjutkan uji ANOVA pada design expert7.1.5. Dari Uji ANOVA yang sudah dilakukan maka didapatkan hasil statistik yang dapat dilihat pada tabel 4.

Tabel 4

\section{Hasil analisis statistik ANOVA respon pH}

\begin{tabular}{ccc}
\hline Source & p-value & kemaknaan \\
\hline Model (linear mixture) & $>0,0092$ & signifikan \\
Lack of fit test & 0,9752 & Tidak signifikan \\
\hline
\end{tabular}

Berdasarkan hasil analisis ANOVA pada tabel 4 diketahui bahwa model yang tepat untuk menerangkan respon $\mathrm{pH}$ adalah linear model. Hal ini terlihat dari p-value model linear yaitu $0,0092(<0,05)$ menunjukkan hasil yang signifikan. Hasil ini diperkuat dengan nilai lack of fit test (ketepatan model) sebesar 0,9752 $(>0.05)$ yang berarti tidak ada perbedaan bermakna antara data observasi dengan data hasil prediksi dari model yang dibuat. Profil variasi dua komponen terhadap respon $\mathrm{pH}$ dilihat pada gambar 2 .

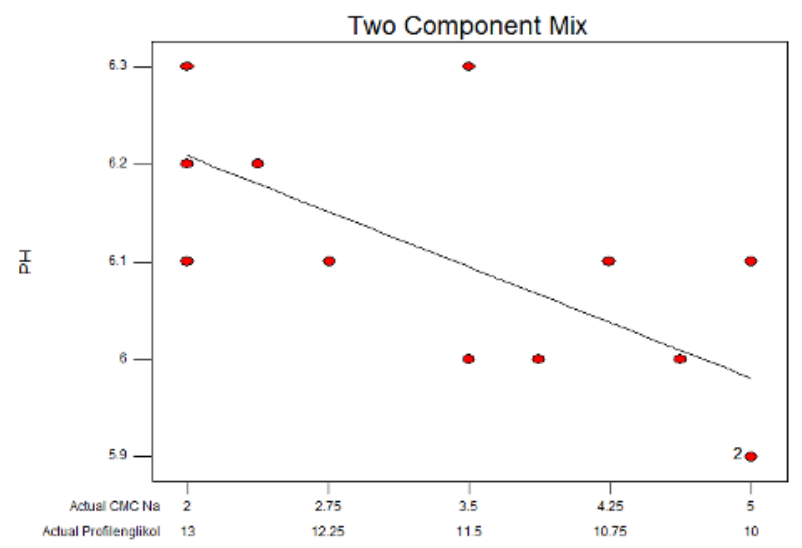

Gambar 2

Variasi dua komponen terhadap respon pH

Persamaan Least Sygnificant Different (pseudo components) yang diperoleh adalah persamaan linear yang dapat dilihat pada persamaan (1)

$\mathrm{Y}_{1}=0,5(\mathrm{~A})+0,5(\mathrm{~B} \ldots \ldots \ldots \ldots \ldots$..........

Keterangan $: \mathrm{Y}_{1}=\mathrm{pH}$

$\mathrm{A}=$ Komposisi CMC-Na

$\mathrm{B}=$ Komposisi Propilen glikol

Berdasarkan persamaan (1) menunjukkan bahwa kedua komponen memberikan pengaruh yang positif yang sama dapat meningkatkan persentase $\mathrm{pH}$. 


\section{Hasil Uji Daya Sebar}

Daya sebar merupakan parameter penting dalam penilaian kemampuan gel untuk menyebar. Sediaan gel dapat dikatakan memenuhi sifat mekanik yang optimal, jika sediaan mudah dikeluarkan dari wadah dan memiliki daya sebar yang baik pada kulit ketika sediaan diaplikasikan sehingga dapat memberikan kenyamanan penggunaan oleh konsumen (Garg et al., 2002). Daya sebar gel diperlihatkan oleh diameter dan luas sebar gel terhadap beban yang ditambahkan. Spesifikasi diameter daya sebar yaitu $5-7 \mathrm{~cm}$ (Garg et al., 2002). Respon daya sebar di uji normalitas mnggunakan Design Expert7.1.5. Analisis kurva normal plot of residual dengan parameter daya sebar tampak pada gambar 3

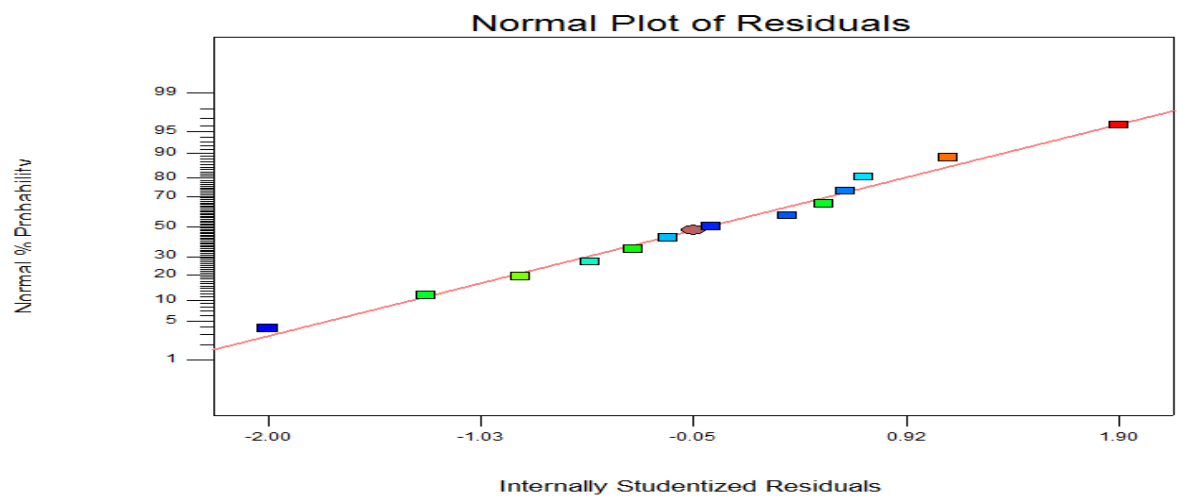

Gambar 3

Kurva Normal Plot Of Residual Respon Daya Sebar

Berdasarkan kurva tersebut, terlihat bahwa data menyebar disekitar garis diagonal dan mengikuti arah garis diagonal yang menandakan bahwa data terdistribusi normal sehingga dapat dilanjutkan uji ANOVA pada design expert 7.1.5.Daru Uji ANOVA yang sudah dilakukan maka didapatkan hasil statistik yang dapat dilihat pada tabel 5 .

Tabel 5

Hasil Analisis ANOVA Design Expert 7.1.5 Respon Daya Sebar

\begin{tabular}{ccc}
\hline Source & p-value & Kemaknaan \\
\hline Model (linier mixture) & 0,0001 & Signifikan \\
Lack of fit test & 0,3207 & Tidak signifikan \\
\hline
\end{tabular}

Berdasarkan hasil analisis ANOVA pada tabel 5 diketahui bahwa model linier merupakan model yang dapat menerangkan respon daya sebar gel, hal ini terlihat dari nilai $p$-value yaitu $0,0001 \quad(<0,05)$ menunjukkan hasil yang significant. Hasil lack of fit test sebesar 0,3207 (>0.05) yang berarti tidak ada perbedaan bermakna antara data observasi dengan data hasil prediksi dari model yang dibuat. Hasil pengujian daya sebar kemudian dianalisis menggunakan Design Expert 7.1.5 untuk melihat pengaruh masing-masing komponen ataupun 
interaksi antar komponen terhadap daya sebar yang dihasilkan. Profil variasi dua komponen terhadap respon daya sebar dapat dilihat pada gambar 4.

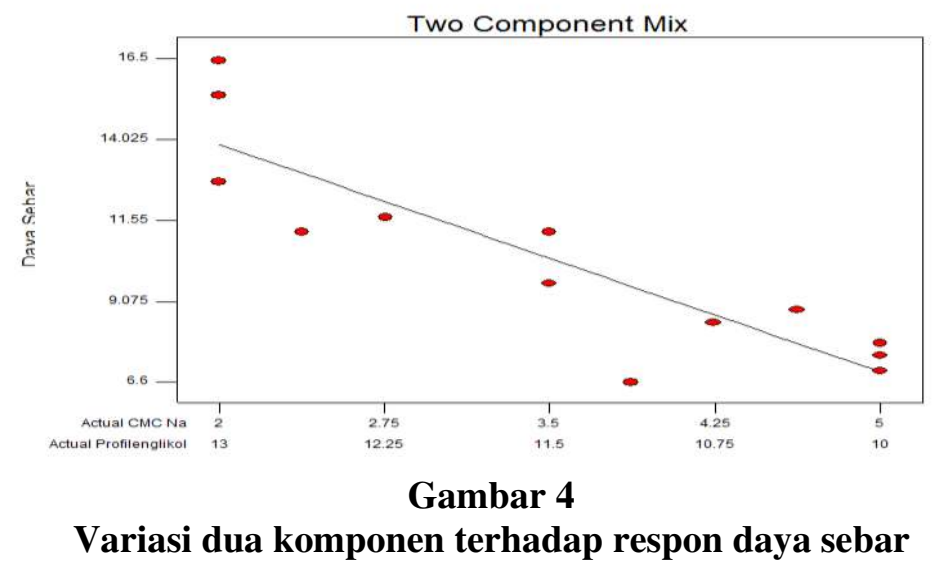

Persamaan Least Sygnificant Different (pseudo components) yang diperoleh adalah persamaan linear yang dapat dilihat pada persamaan (2).

$\mathrm{Y}_{1}=+0,50(\mathrm{~A})+0,50(\mathrm{~B})$ .Persamaan (2)

Keterangan $: \mathrm{Y}_{1}=$ Daya Sebar

$\mathrm{A}=$ Komposisi CMC-Na

$\mathrm{B}=$ Komposisi Propilen glikol

Berdasarkan persamaan (2) menunjukkan bahwa Kedua komponen ini memberikan pengaruh yang positif terhadap peningkatan persentase daya sebar dengan nilai koefisien yaitu $+0,50$.

\section{Hasil Daya Lekat}

Pengujian daya lekat bertujuan untuk mengetahui waktu yang dibutuhkan gel tersebut untuk melekat pada kulit. Daya lekat yang baik memungkinkan obat tidak mudah terlepas dan semakin lama melekat pada kulit, sehingga dapat menghasilkan efek yang diinginkan. Persyaratan daya lekat yang baik untuk sediaan topikal adalah $\geq 4$ detik (Mukhlishah, Sugihartini and Yuwono, 2016). Adapun hasil respon daya lekat pada 13 run memenuhi persyaratan, dapat dilihat pada tabel 3. Respon daya lekat dengan uji normalitas menggunakan Design Expert 7.1.5. Analisis kurva normal plot of residuals terhadap respon daya lekat dapat dilihat pada gambar 5 .

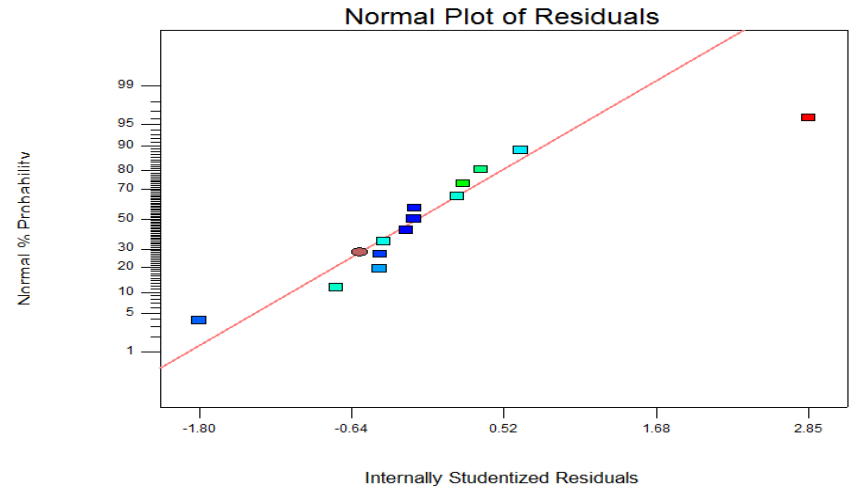

Gambar 5

Normalplot of residuals terhadap respon daya lekat 
Berdasarkan kurva diatas, terlihat bahwa data menyebar disekitar garis diagonal dan mengikuti arah garis diagonal yang menandakan bahwa data terdistribusi normal sehingga dapat dilanjutkan uji ANOVA pada design expert 7.1.5. Dari Uji ANOVA yang sudah dilakukan maka didapatkan hasil statistik yang dapat dilihat pada tabel 6.

Tabel 6

Hasil Analisis ANOVA Design Expert 7.1.5 Respon Daya Lekat

\begin{tabular}{lcc}
\hline \multicolumn{1}{c}{ Source } & p-value & Kemaknaan \\
\hline Model (linear mixture) & 0,0277 & Significant \\
Lack of fit test & 0,0644 & Not significant \\
\hline
\end{tabular}

Berdasarkan hasil analisis ANOVA pada tabel 6 diketahui bahwa model yang dapat menerangkan respon daya lekat gel, hal ini terlihat dari $p$-value model linear yaitu $0,0277(<0,05)$ menunjukkan hasil yang significant. Hasil lack of fit test sebesar $0,0644(>0.05)$ yang berarti tidak ada perbedaan bermakna antara data observasi dengan data hasil prediksi.

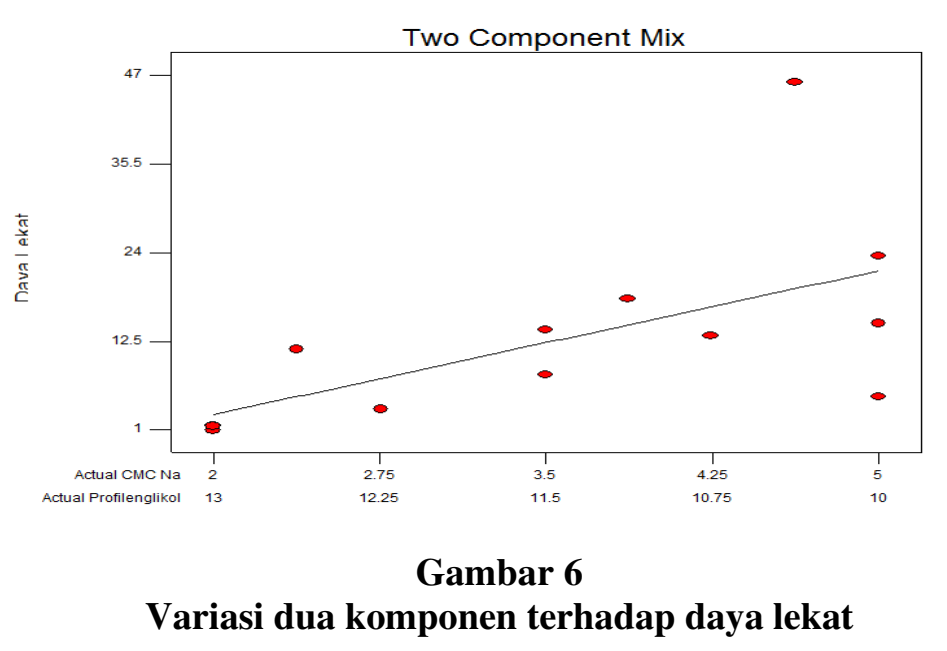

Persamaan Least Sygnificant Different (pseudo components) yang diperoleh adalah persamaan linear yang dapat dilihat pada persamaan (3)

$\mathrm{Y}_{1}=+0,50(\mathrm{~A})+0,50$ (B) $\ldots \ldots \ldots \ldots \ldots$...Persamaan (3)

Keterangan $: \mathrm{Y}_{1}=$ Daya Lekat

$\mathrm{A}=$ Komposisi CMC-Na

$\mathrm{B}=$ Komposisi Propilen glikol

Berdasarkan persamaan (3) menunjukkan bahwa Kedua komponen ini memberikan pengaruh yang positif terhadap peningkatan persentase daya lekat dengan nilai koefisien yaitu $+0,50$.

\section{Formula Optimal Gel Ekstrak Limbah Tomat}

Formula paling optimal adalah formula dengan nilai desirability maksimum. Desirability yang semakin mendekati nilai 1,0 menunjukkan kemampuan design menghasilkan formula yang mendekati sempurna(Nurmiah et al., 2013). 
Komponen formula gel yang dioptimasi adalah CMC-Na dan Propilen glikol dan respon yang digunakan adalah uji $\mathrm{pH}$, daya sebar dan daya lekat. Setiap komponen dan respon dilakukan pembobotan kepentingan untuk memperoleh respon optimal yang diinginkan. Pembobotan kepentingan ini disebut juga importance, dimana terdapat pilihan tanda positif satu (+) hingga positif lima $(+++++)$. Semakin tinggi tingkat kepentingan dari komponen dan respon yang diukur, maka semakin besar bobot kepentingan yng diberikan. Bobot kepentingan dan target respon formula gel dapat dilihat pada tabel 7

Tabel 7

Optimasi Formula Gel Ekstrak Limbah Tomat

\begin{tabular}{lcccc}
\hline Nama & Target & Lower limit & Upper limit & Importance \\
\hline CMC-Na & In range & 2 & 5 & 3 \\
Propilen glikol & Target & 10 & 13 & 3 \\
$\mathrm{pH}$ & In range & 5,9 & 6,3 & 3 \\
Daya lekat & In ringe & 1 & 46,1 & 3 \\
Daya sebar & Target $\rightarrow$ & 6,60185 & 16,4305 & 3 \\
\hline
\end{tabular}

Komponen $\mathrm{CMC}-\mathrm{Na}$ dioptimalkan dengan In range dan Propileglikol tertarget keduanya mempunyai nilai importance yang sama sebesar tiga $(+++)$,artinya kedua komponen memiliki peran yang sama dalam menentukan formula yang optimum. Formula yang disarankan oleh program Design Expert 7.1.5 sebanyak satu (1) solusi formula yang terlihat pada tabel 8 .

Tabel 8

Formula yang disarankan oleh Design Expert 7.1.5

\begin{tabular}{cccccc}
\hline $\mathbf{A}(\boldsymbol{\%})$ & $\mathbf{B}(\boldsymbol{\%})$ & $\mathbf{p H}$ & $\begin{array}{c}\text { Daya Sebar } \\
\left(\mathbf{c m}^{\mathbf{2}}\right)\end{array}$ & $\begin{array}{r}\text { Daya } \\
\text { Lekat } \\
(\mathbf{d t k})\end{array}$ & Decirability \\
\hline $\mathbf{3 , 5 0 0 \%}$ & $11,500 \%$ & 6,09446 & 10,3839 & 12,3177 & 0,88 \\
\hline Keterangan : & $\begin{array}{c}\text { A } \\
\text { B } \text { CMC-Na Propilen glikol }\end{array}$ & & & \\
&
\end{tabular}

Berdasarkan gambar, nilai desirability yang diperoleh melalui optimasi ini adalah 0,88. Desirability adalah nilai target dari suatu optimasi yang ingin dicapai. Nilainya berkisar antara 0-1. Apabila nilai desirability makin mendekati satu, maka hal tersebut menunjukan semakin tingginya kesesuian formula yang diperoleh untuk mencapai formula optimum dengan variabel respon yang dikehendak. Titik perpotongan hasil formula optimal dapat dilihat pada countour plot dengan nilai desirability sebesar 0,88 pada gambar 7 . 


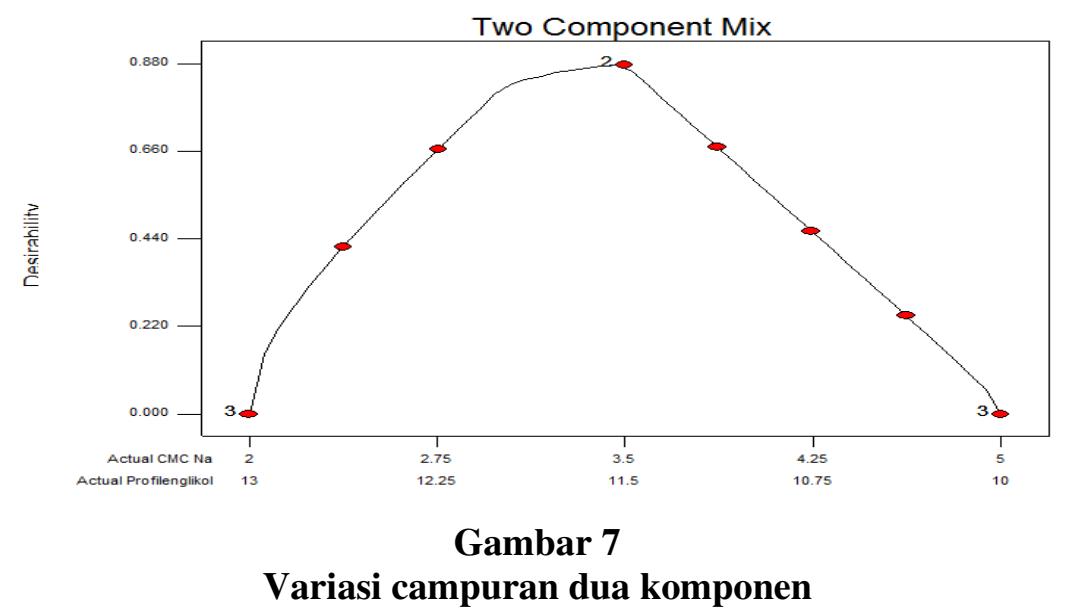

\section{Uji Stabilitas Fisik dengan Metode Cyling Test}

Gel disimpan pada suhu $10^{\circ} \mathrm{C}$ selama 24 jam lalu dikeluarkan dan ditempatkan pada suhu $30^{\circ} \mathrm{C}$ selama 24 jam. Perlakuan ini adalah satu siklus. Percobaan diulang sebanyak 3 siklus. Dari hasil pengujian dapat dilihat ada atau tidak terjadi sineresis. Sineresis adalah proses dimana cairan terpisah dari gel. Pada penelitian ini didapatkan hasil yang tertera pada tabel 9.

Tabel 9

Hasil Uji Cyling Test

\begin{tabular}{cc}
\hline Formula & Hasil \\
\hline F1 & Tidak terjadi sineresis \\
F2 & Tidak terjadi sineresis \\
F3 & Tidak terjadi sineresis \\
\hline
\end{tabular}

Berdasarkan tabel di atas bahwa gel ekstrak limbah daging tomat tidak mengalami sineresis, hal ini menunjukan bahwa pada penyimpanan suhu $10^{\circ} \mathrm{C}$ dan suhu $30^{\circ} \mathrm{C}$ stabil. Penyebab sineresis yaitu sediaan terlalu lama diletakkan atau disimpan di udara terbuka, dan terjadi kenaikan suhu. Hal ini mengakibatkan adanya kontraksi di dalam massa gel. Cairan yang terjerat akan keluar dan berada di atas permukaan gel.

\section{Uji Aktifitas Terhadap Lama Penyembuhan Luka insisi Formula Optimum Gel}

Pengujian aktivitas gel ekstrak limbah daging tomat dilakukan pada kulit punggung kelinci yang disayat lalu diberikan perlakuan berupa betadin (kontrol positif), formula optimum gel, gel tanpa ekstrak/basis (kontrol negatif) dan tanpa perlakuan. Masing-masing dioleskan pada area luka dimana pengolesan dilakukan 2 kali sehari dengan 3 kali replikasi pada setiap kelompok perlakuan, selama pengolesan diamati dengan mengukur panjang luka yang terjadi menggunakan penggaris satuan $\mathrm{cm}$. Setelah dilakukan pengamatan terhadap panjang luka setiap 
hari hingga hari ketujuh, data kemudian diuji statistik dengan metode anova maka didapatkan hasil penutupan luka seperti terlihat pada tabel 10.

Tabel 10

Mean \pm SD Penyembuh Luka

\begin{tabular}{|c|c|c|c|c|c|c|}
\hline \multirow{2}{*}{$\begin{array}{c}\text { Kelompo } \\
\mathbf{k}\end{array}$} & \multicolumn{6}{|c|}{ Mean \pm Sd Panjang Luka ( cm) } \\
\hline & Hari ke-2 & Hari ke-3 & Hari ke-4 & Hari ke-5 & Hari ke-6 & Hari ke-7 \\
\hline betadin & $\begin{array}{l}2.433 \pm 0.05 \\
8^{a}\end{array}$ & $1.967 \pm 0.058^{\mathrm{a}}$ & $\begin{array}{l}0.967 \pm 0.05 \\
8^{a}\end{array}$ & $\begin{array}{l}0.667 \pm 0.05 \\
8^{a}\end{array}$ & $\begin{array}{l}0.300 \pm 0.10 \\
0^{\mathrm{a}}\end{array}$ & $\begin{array}{l}0.000 \pm 0.00 \\
0^{\mathrm{a}}\end{array}$ \\
\hline $\begin{array}{l}\text { Formula } \\
\text { optimum }\end{array}$ & $\begin{array}{l}2.567 \pm 0.05 \\
8^{b}\end{array}$ & $\begin{array}{l}2.333 \pm 0.058 \\
\mathrm{~b}\end{array}$ & $\begin{array}{l}1.567 \pm 0.05 \\
8^{b}\end{array}$ & $\begin{array}{l}1.100 \pm 0.10 \\
0^{\mathrm{b}}\end{array}$ & $0.767 \pm .058^{\mathrm{b}}$ & $\begin{array}{l}0.433 \pm 0.05 \\
8^{b}\end{array}$ \\
\hline Basis & $\begin{array}{l}2.733 \pm 0.05 \\
8^{c}\end{array}$ & $\begin{array}{l}2.667 \pm 0.058 \\
4^{\mathrm{c}}\end{array}$ & $2.567 \pm .058^{\mathrm{c}}$ & $\begin{array}{l}2.467 \pm 0.05 \\
8^{c}\end{array}$ & $2.367 \pm .058^{\mathrm{c}}$ & $\begin{array}{l}2.167 \pm 0.05 \\
8^{c}\end{array}$ \\
\hline $\begin{array}{l}\text { Tanpa } \\
\text { perlakuan }\end{array}$ & $\begin{array}{l}2.767 \pm 0.05 \\
8^{c}\end{array}$ & $2.667 \pm 0.058^{\mathrm{c}}$ & $2.567 \pm .058^{\mathrm{c}}$ & $\begin{array}{l}2.467 \pm 0.05 \\
8^{c}\end{array}$ & $\begin{array}{l}2.367 \pm 0.05 \\
8^{c}\end{array}$ & $\begin{array}{l}2.167 \pm 0.05 \\
8^{c}\end{array}$ \\
\hline
\end{tabular}

Keterangan : Simbol a"b"c" yang sama menunjukkan tidak adanya perbedaan signifikan antar kelompok perlakuan $(\mathrm{P}<0,05)$

Berdasarkan hasil uji Anova untuk aktivitas penyembuhan luka insisi pada kelinci telah dipaparkan pada tabel 10 dengan melihat rata-rata pengukuran luka setiap harinya. Pada masing-masing kelompok (betadin, formula optimum, basis, tanpa perlakuan) memberikan perbedaan yang signifikan terhadap panjang luka dari hari pertama sampai hari ketujuh $(\mathrm{P}<0,05)$. Formula optimum ekstrak daging limbah tomat lebih efektif sebagai penyembuh luka insisi, karena penutupan luka yg lebih cepat dibandingkan dengan plasebo atau basis gel

\section{SIMPULAN DAN SARAN}

\section{Simpulan}

Berdasarkan hasil penelitian dapat disimpulkan bahwa :

1. Porsentase formula optimum bahan teroptimasi gel serbuk getah ashitaba yang dihasilkan untuk CMC-Na dan Propilenglikol masing-masing adalah $3,50 \%$ dan $11,50 \%$.

2. Parameter mutu fisik formula optimum gel serbuk getah ashitaba yang dihasilkan untuk nilai pH 6,094, daya sebar $10,383 \mathrm{~cm}^{2}$, daya lekat 12,317 detik serta menunjukkan stabilitas yang baik selama proses penyimpanan.

3. Gel ekstrak limbah daging tomat berpotensi sebagai alternative obat luka insisi. Dilihat pada hari ke 7 pengamatan terdapat perbedaan yang signifikan antara formula optimum dengan basis maupun tanpa perlakuan.

\section{DAFTAR PUSTAKA}

Afiyanti and Rachmawati (2014) Metodologi Penelitian Kualitatif dalam Riset Keperawatan. Jakarta.Salemba.

Agoes, G. (2007) Teknologi bahan alam. Jakarta: Institut Teknologi Bandung. 
Aponno, J. V. (2014) 'Uji Efektivitas Sediaan Gel Ekstrak Etanol daun Jambu Biji (Psidium guajava Linn) Terhadap Penyembuhan Luka yang Terinfeksi Bakteri Staphylococcus aureus pada Kelinci (Orytolagus cuniculus)', PHARMACON, 3(3).

Chaudhary, H. et al. (2011) 'Optimization and Formulation Design of Gels of Diclofenac and Curcumin for Transdermal Drug Delivery by Box-Behnken Statistical Design', Journal of Pharmaceutical Sciences, 100(2), pp. 580593. doi: 10.1002/jps.22292.

Departement Kesehatan (2000) Parameter Standar Umum Ekstrak Tumbuhan Obat. bahratara: Direktorat Jendral Pengawasan Obat dan Makan.

Farmasi, J. (2014) 'Formulasi, Uji Stabilitas Fisik, Dan Uji Aktifitas Sediaan Gel Hand Sanitizer Dari Air Perasan Jeruk Nipis ( Citrus Aurantifolia Swingle ) Berbasis Karbomer', 2(1), pp. 28-34.

Garg, A. et al. (2002) 'Spreading of semisolid formulations', Pharmaceutical technology, (September), pp. 84-105. doi: 10.5138/ijdd.2010.0975.0215.02012.

Librianty, N. (2015) 'Panduan Mandiri Melacak Penyakit', in. Jakarta.

Mukhlishah, N. R. I., Sugihartini, N. and Yuwono, T. (2016) 'Daya Iritasi Dan Sifat Fisik Sediaan Salep Minyak Atsiri Bunga Cengkeh ( Syzigium Aromaticum ) Pada Basis Hidrokarbon Unguentum Volatile Oil Of Syzygium Aromaticum', 12(1), pp. 372-376.

Nurmiah, S. et al. (2013) 'Aplikasi Response Surface Methodology Pada Optimalisasi Kondisi Proses Pengolahan Alkali Treated Cottonii ( ATC ) Process Conditions Of Alkali Treated Cottonii ( ATC ) Processing', pp. 922.

Purwanto, P., Mufrod, M. and NSP, A. S. (2015) 'Antioxidant Activity Of Cream Dosage Form Of Tomato Extract (Solanum Lycopersicum L.)', Traditional Medicine Journal, 18(3), pp. 132-140.

Ramdani, N. F., Mambo, C. and Wuisan, J. (2014) 'Uji Efek Daun Kemangi ( Ocimum Basilicum L .) Terhadap Penyembuhan Luka Insisi Pada Kelinci ( Oryctolagus Cuniculus )', 3, p. 3.

Rowe, R.C., Sheskey, P. J., Owen, S. C. (2006) Handbook of Pharmaceutical Exipiens. 5th edn. London: American Pharmaceutical Association.

Sjamsu, H. (2005) Buku Ajar Ilmu Bedah. EGC. Jakarta.

Soebagio, B. and Rusdiana, T. (2007) 'Pembuatan Gel Dengan Aqupec HV-505 dari Ekstrak Umbi Bawang Merah (Allium cepa, L.) Sebagai Antioksidan', Abstrak.

Suhartati, R. (2015) 'Potensi Antibakteri Limbah Tomat (Lycopersicum Esculentum Mill) Terhadap Bakteri Staphylococcus Aureus', Jurnal Kesehatan Bakti Tunas Husada, 13(1).

Sumardiono, S., Basri, M. and Pasonang Sihombing, R. (2009) 'Analisis SifatSifat Psiko-Kimia Buah Tomat (Lycopersicon Esculentum) Jenis Tomat Apel, Guna Peningkatan Nilai Fungsi Buah Tomat Sebagai Komoditi Pangan Lokal'. R. A22 Jurusan teknik Kimia Fakultas Teknik UNDIP.

Tiaraswara, R. A. (2015) 'Optimalisasi Formulasi Hard Candy Ekstrak Daun Mulberry ( Morus Sp . ) Dengan Menggunakan Design Expert Metode D- 
Optimal Program Studi Teknologi Pangan.'

Tranggono, R.I., \& L. (2007) 'Buku Pengantar limu Kosmetik'. Pustaka Utama, Jakarta, p. 6-8, 11-13, 30-3 1, 129.

Wombeogo and Kuubire (2014) Traumaand Emergency Health Care Manual. Bloomington: Author House. 


\section{PEDOMAN PENULISAN NASKAH JURNAL "CENDEKIA JOURNAL OF PHARMACY"}

\section{TUJUAN PENULISAN NASKAH}

Penerbitan Jurnal Ilmiah "Cendekia Journal Pharmacy" ditujukan untuk memberikan informasi hasil- hasil penelitian dalam bidang ilmu dan teknologi Farmasi.

\section{JENIS NASKAH}

Naskah yang diajukan untuk diterbitkan dapat berupa: penelitian, tinjauan kasus, dan tinjauan pustaka/literatur. Naskah merupakan karya ilmiah asli dalam lima tahun terakhir dan belum pernah dipublikasikan sebelumnya. Ditulis dalam bentuk baku (MS Word) dan gaya bahasa ilmiah, tidak kurang dari 10 halaman, tulisan times new roman ukuran 12 font, ketikan 1 spasi, jarak tepi $3 \mathrm{~cm}$, dan ukuran kertas A4. Naskah menggunakan bahasa Indonesia baku, setiap kata asing diusahakan dicari padanannya dalam bahasa Indonesia baku, kecuali jika tidak ada, tetap dituliskan dalam bahasa aslinya dengan ditulis italic. Naskah yang telah diterbitkan menjadi hak milik redaksi dan naskah tidak boleh diterbitkan dalam bentuk apapun tanpa persetujuan redaksi. Pernyataan dalam naskah sepenuhnya menjadi tanggung jawab penulis.

\section{FORMAT PENULISAN NASKAH}

Naskah diserahkan dalam bentuk softile dan print-out 2 eksemplar. Naskah disusun sesuai format baku terdiri dari: Judul Naskah, Nama Penulis, Abstrak, Latar Belakang, Metode, Hasil dan Pembahasan, Simpulan dan Saran, Daftar Pustaka.

\section{Judul Naskah}

Judul ditulis secara jelas dan singkat dalam bahasa Indonesia yang menggambarkan isi pokok/variabel, maksimum 20 kata. Judul diketik dengan huruf Book Antique, ukuran font 13, bold UPPERCASE, center, jarak 1 spasi.

\section{Nama Penulis}

Meliputi nama lengkap penulis utama tanpa gelar dan anggota (jika ada), disertai nama institusi/instansi, alamat institusi/instansi, kode pos, PO Box, e-mailpenulis, dan no telp. Data Penulis diketik dengan huruf Times New Roman, ukuran font 11, center, jarak 1spasi

\section{Abstrak}

Ditulis dalam bahasa inggris dan bahasa Indonesia, dibatasi 250-300 kata dalam satu paragraf, bersifat utuh dan mandiri.Tidak boleh ada referensi. Abstrak terdiri dari: latar belakang, tujuan, metode, hasil analisa statistik, dan kesimpulan. Disertai kata kunci/ keywords. 
Abstrak dalam Bahasa Indonesia diketik dengan huruf Times New Roman, ukuran font 11, jarak 1 spasi. Abstrak Bahasa Inggris diketik dengan huruf Times New Roman, ukuran font 11, italic, jarak 1spasi.

\section{Latar Belakang}

Berisi informasi secara sistematis/urut tentang: masalah penelitian, skala masalah, kronologis masalah, dan konsep solusiyang disajikan secara ringkas dan jelas.

\section{Bahan dan Metode Penelitian}

Berisi tentang: jenis penelitian, desain, populasi, jumlah sampel, teknik sampling, karakteristik responden, waktu dan tempat penelitian, instrumen yang digunakan, serta uji analisis statistik yang digunakan disajikan dengan jelas.

\section{Hasil dan Pembahasan}

Hasil penelitian hendaknya disajikan secara berkesinambungan dari mulai hasil penelitian utama hingga hasil penunjang yang dilangkapi dengan pembahasan. Hasil dan pembahasan dapat dibuat dalam suatu bagian yang sama atau terpisah. Jika ada penemuan baru, hendaknya tegas dikemukakan dalam pembahasan. Nama tabel/diagram/gambar/skema, isi beserta keterangannya ditulis dalam bahasa Indonesia dan diberi nomor sesuai dengan urutan penyebutan teks. Satuan pengukuran yang digunakan dalam naskah hendaknya mengikuti sistem internasional yang berlaku.

\section{Simpulan dan Saran}

Kesimpulan hasil penelitian dikemukakan secara jelas. Saran dicantumkan setelah kesimpulan yang disajikan secara teoritis dan secara praktis yang dapat dimanfaatkan langsung oleh masyarakat.

\section{Ucapan Terima Kasih (apabila ada)}

Apabila penelitian ini disponsori oleh pihak penyandang dana tertentu, misalnya hasil penelitian yang disponsori oleh DP2M DIKTI, DINKES, dsb.

\section{Daftar Pustaka}

Sumber pustaka yang dikutip meliputi: jurnal ilmiah, skripsi, tesis, disertasi, dan sumber pustaka lain yang harus dicantumkan dalam daftar pustaka. Sumber pustaka disusun berdasarkan sistem Harvard. Jumlah acuan minimal 10 pustaka (diutamakan sumber pustaka dari jurnal ilmiah yang uptodate 10 tahun sebelumnya). Nama pengarang diawali dengan nama belakang dan diikuti dengan singkatan nama di depannya. Tanda " $\&$ " dapat digunakan dalam menuliskan nama-nama pengarang, selama penggunaannya bersifat konsisten. Cantumkan semua penulis bila tidak lebih dari 6 orang. Bila lebih dari 6 orang, tulis nama 6 penulis pertama dan selanjutnya dkk.

Daftar Pustaka diketik dengan huruf Times New Roman, ukuran font 12, jarak 1 spasi.

\section{TATA CARA PENULISAN NASKAH}

Anak Judul : Jenis huruf Times New Roman, ukuran font 12, Bold UPPERCASE Sub Judul : Jenis huruf Times New Roman, ukuran font 12, Bold, Italic

Kutipan : Jenis huruf Times New Roman, ukuran font 10, italic 
Tabel : Setiap tabel harus diketik dengan spasi 1, font 11 atau disesuaikan. Nomor tabel diurutkan sesuai dengan urutan penyebutan dalam teks (penulisan nomor tidak memakai tanda baca titik “.”). Tabel diberi judul dan subjudul secara singkat. Judul tabel ditulis diatas tabel. Judul tabel ditulis dengan huruf Times New Roman dengan font 11, bold (awal kalimat huruf besar) dengan jarak 1 spasi, center. Antara judul tabel dan tabel diberi jarak 1 spasi. Bila terdapat keterangan tabel, ditulis dengan font 10, spasi 1, dengan jarak antara tabel dan keterangan tabel 1 spasi. Kolom didalam tabel tanpa garis vertical. Penjelasan semua singkatan tidak baku pada tabel ditempatkan pada catatan kaki.

Gambar : Judul gambar diletakkan di bawah gambar. Gambar harus diberi nomor urut sesuai dengan pemunculan dalam teks. Grafik maupun diagram dianggap sebagai gambar. Latar belakang grafik maupun diagram polos. Gambar ditampilkan dalam bentuk 2 dimensi. Judul gambar ditulis dengan huruf Times New Roman dengan font 11, bold (pada tulisan "gambar 1"), awal kalimat huruf besar, dengan jarak 1 spasi, center Bila terdapat keterangan gambar, dituliskan setelah judul gambar.

Rumus : ditulis menggunakan Mathematical Equation, center

Perujukan : pada teks menggunakan aturan (penulis, tahun)

\section{Contoh Penulisan Daftar Pustaka :}

\section{Bersumber dari buku atau monograf lainnya}

i. Penulisan Pustaka Jika ada Satu penulis, dua penulis atau lebih :

Sciortino, R. (2007) Menuju Kesehatan Madani. Yogyakarta: Gadjah Mada University Press.

Shortell, S. M. \& Kaluzny A. D. (1997) Essential of health care management. New York: Delmar Publishers.

Cheek, J., Doskatsch, I., Hill, P. \& Walsh, L. (1995) Finding out: information literacy for the 21st century. South Melbourne: MacMillan Education Ausralia.

ii. Editor atau penyusun sebagai penulis:

Spence, B. Ed. (1993) Secondary school management in the 1990s: challenge and change. Aspects of education series, 48. London: Independent Publishers.

Robinson, W.F.\&Huxtable,C.R.R. eds.(1998) Clinicopathologic principles for veterinary medicine. Cambridge: Cambridge University Press.

iii. Penulis dan editor:

Breedlove, G.K.\&Schorfeide, A.M.(2001)Adolescent pregnancy.2nded.

Wiecrozek, R.R.ed.White Plains (NY): March of Dimes Education Services.

iv. Institusi, perusahaan, atau organisasi sebagai penulis:

Depkes Republik Indonesia (2004) Sistem kesehatan nasional. Jakarta: Depkes.

2. Salah satu tulisan yang dikutip berada dalam buku yang berisi kumpulan 


\section{berbagai tulisan.}

Porter, M.A. (1993) The modification of method in researching postgraduate education. In: Burgess, R.G.ed. The research process in educational settings: ten case studies. London: Falmer Press, pp.35-47.

3. Referensi kedua yaitu buku yang dikutip atau disitasi berada di dalam buku yang lain

Confederation of British Industry (1989) Towards a skills revolution: a youth charter. London: CBI. Quoted in: Bluck, R., Hilton, A., \& Noon, P. (1994) Information skills in academic libraries: a teaching and learning role i higher education. SEDA Paper 82. Birmingham: Staff and Educational Development Association, p.39.

\section{Prosiding Seminar atau Pertemuan}

ERGOB Conference on Sugar Substitutes, 1978. Geneva, (1979). Health and Sugar Substitutes: proceedings of the ERGOB conference on sugar substitutes, Guggenheim, B. Ed. London: Basel.

\section{Laporan Ilmiah atau Laporan Teknis}

Yen, G.G (Oklahoma State University, School of Electrical and Computer Engineering, Stillwater, OK). (2002, Feb). Health monitoring on vibration signatures. Final Report. Arlington (VA): Air Force Office of AFRLSRBLTR020123. Contract No.: F496209810049

6. Karya Ilmiah, Skripsi, Thesis, atau Desertasi

Martoni (2007) Fungsi Manajemen Puskesmas dan Partisipasi Masyarakat Dalam Kegiatan Posyandu di Kota Jambi. Tesis, Universitas Gadjah Mada.

\section{Artikel jurnal}

a. Artikel jurnal standard

Sopacua, E. \& Handayani,L.(2008) Potret Pelaksanaan Revitalisasi Puskesmas. Jurnal Manajemen Pelayanan Kesehatan, 11: 27-31.

b. Artikel yang tidak ada nama penulis

How dangerous is obesity? (1977) British Medical Journal, No. 6069, 28 April, p. 1115.

c. Organisasi sebagai penulis

Diabetes Prevention Program Research Group. (2002) Hypertension, insulin, and proinsulin in participants with impaired glucose tolerance. Hypertension, 40 (5), pp. 679-86

d. Artikel Koran

Sadli,M.(2005) Akan timbul krisis atau resesi?. Kompas, 9 November, hal. 6.

\section{Naskah yang tidak di publikasi}

Tian,D.,Araki,H., Stahl, E., Bergelson, J., \& Kreitman, M. (2002) Signature of balancing selection in Arabidopsis. Proc Natl Acad Sci USA. In Press.

9. Buku-buku elektronik (e-book)

Dronke, P. (1968) Medieval Latin and the rise of European love- lyric [Internet].Oxford: Oxford University Press. Available from: 
netLibraryhttp://www.netlibrary.com/ urlapi.asp?action=summary $\& \mathrm{v}=1 \&$ bookid=22981 [Accessed 6 March 2001]

\section{Artikel jurnal elektronik}

Cotter, J. (1999) Asset revelations and debt contracting. Abacus [Internet], October, 35 (5) pp. 268-285. Available from: http://www.ingenta.com [Accessed 19

November 2001].

\section{Web pages}

Rowett, S.(1998)Higher Education for capability: automous learning for life and work[Internet],Higher Education for capability.Available from:http://www.lle. mdx.ac.uk[Accessed10September2001]

\section{Web sites}

Program studi S2 Ilmu Kesehatan Masyarakat UGM. (2005) Program studi S2 Ilmu Kesehatan Masyarakat UGM [Internet]. Yogyakarta: S2 IKM UGM. Tersedia dalam: http://ph-ugm.org [Accessed 16 September 2009].

\section{Email}

Brack, E.V. (1996) Computing and short courses. LIS-LINK 2 May 1996

[Internet discussion list]. Available from mailbase@mailbase.ac.uk [Accessed 15 April 1997]. 